Al-Mashrafiyah: Jurnal Ekonomi, Keuangan dan Perbankan Syariah

ISSN (p): 2597-4904 ISSN (e) : 2620-5661

Volume 4 , Nomor 2 , Oktober (2020), h. 1-14

https://doi.org/10.24252/al-mashrafiyah.v4i2.13375

\title{
Praktik Income Smoothing dan Potensi Displaced Commercial Risk Pada Sukuk Mudharabah
}

\author{
Singgih Rasyitu Brahim \\ Magister Ekonomi dan Keuangan \\ Universitas Islam Indonesia \\ email: brahimsinggih@gmail.com \\ Rifqi Muhammad \\ Program Studi Akuntansi \\ Universitas Islam Indonesia \\ email: rifqimuhammad@uii.ac.id
}

\begin{abstract}
Keywords:

Mudharabah

Sukuk,

Displaced

Commercial

Risk (DCR),

Income

smoothing.

This paper aims to discuss the implementation of one of the mudharabah sukuk issued by corporations. Furthermore, the paper specifically discusses indications of Income Smoothing practices and the potential for Displaced Commercial Risk (DCR) in the implementation of sukuk with mudharabah contracts. The type of research uses qualitative methods in the form of library research with a descriptive approach. This paper reveals the fact that there is a practice of Income Smoothing in the distribution of profit sharing to investors in Sukuk. Mudharabah PT SMI. On the other hand, mudharabah sukuk also has DCR potential that will be experienced by investors because the nature of the investment is not classified as sufficiently liquid compared to other investment models and has a relatively high risk. Therefore, a special scheme and regulations are needed for sukuk mudaraba in terms of overcoming the problem of income smoothing and preventing the occurrence of DCR.
\end{abstract}

\section{ABSTRAK}

Kata Kunci:

Sukuk

Mudharabah,

Displaced

Commercial

Risk (DCR),

Income

smoothing
Paper ini bertujuan membahas implementasi salah satu sukuk mudharabah yang dikeluarkan oleh korporasi. Selanjutnya, paper secara khusus membahas indikasi adanya praktik Income Smoothing dan potensi terjadinya Displaced Commercial Risk (DCR) dalam implementasi sukuk dengan akad mudharabah. Jenis penelitian menggunakan metode kualitatif dalam bentuk riset kepustakaan dengan pendekatan deskriptif. Paper ini mengungkapkan fakta bahwa terdapat praktik Income Smoothing dalam distribusi bagi hasil kepada investor pada Sukuk Mudharabah PT SMI. Disisi lain sukuk mudharabah juga memiliki potensi DCR yang akan dialami oleh investor karena sifat investasi yang tidak tergolong cukup liquid dibandingkan model investasi lainnya serta memiliki risiko yang tergolong tinggi. Oleh karena itu diperlukannya skema dan juga regulasi khusus untuk sukuk mudharabah dalam hal mengeliminasi adanya praktik income smoothing dan mencegah terjadinya DCR. 


\section{PENDAHULUAN}

Perkembangan dunia keuangan dan pasar modal dewasa ini memunculkan beragam inovasi yang mana produk tersebut dapat menjadi sumber modal dalam menjalankan usaha. Bukan hanya dalam sudut pandang pengusaha yang menjadikan perkembangan industri keuangan sebagai angin segar dalam menjalankan usahanya, namun dalam sudut investor hal ini merupakan peluang untuk mendiversifikasi portolio investasinya pada instrumen yang mendatangkan profit yang lebih. Salah satu bukti perkembangan industri keuangan yakni dengan munculnya pasar modal yang mana dalam pasar modal terdapat pasar modal umum atau konvensional dan syariah. Salah satu instrumen pasar modal syariah adalah sukuk atau dalam konvensional disebut obligasi. Sukuk secara garis besar merupakan sebuah instrumen yang berbentuk selembar kertas yang menyatakan bahwa pemilik kertas tersebut ikut serta dalam menanamkan modalnya kepada lembaga atau perusahaan yang menerbitkan sukuk sebagai bentuk penyertaan dana (Fadhilah, 2011). Perkembangan sukuk di Indonesia dari tahun ke tahun terus mengalami kenaikan. Hal terlihat dari tabel 1 tentang nilai dan jumlah outstanding sukuk yang disajikan oleh Otoritas Jasa Keuangan (OJK) tahun 2019 dimana perkembangan sukuk korporasi pada nilai outstandingnya sebesar 29.829,500.000, jumlah sukuk outstanding sebanyak 143 sukuk, nilai akumulasi penerbitan sebesar 48.240.400.000, dan akumulasi jumlah penerbitan sukuk sebanyak 232 sukuk.

Tabel 1. Nilai dan Jumlah Outstanding Sukuk

\begin{tabular}{|c|c|c|c|c|}
\hline Tahun & $\begin{array}{c}\text { Nilai outstanding } \\
\text { (Rp Miliar) }\end{array}$ & $\begin{array}{c}\text { Jumlah sukuk } \\
\text { outstanding }\end{array}$ & $\begin{array}{c}\text { Nilai akumulasi } \\
\text { penerbitan (Rp } \\
\text { Miliar) }\end{array}$ & $\begin{array}{c}\text { Akumulasi jumlah } \\
\text { sukuk penerbitan }\end{array}$ \\
\hline 2014 & 9.000 & 50 & 40.000. & 70 \\
\hline 2015 & 10.000 & 57 & 19.000 & 85 \\
\hline 2016 & 12.000 & 60 & 20.000 & 100 \\
\hline 2017 & 16.000 & 85 & 28.000 & 135 \\
\hline 2018 & 21.000 & 100 & 37.000 & 180 \\
\hline 2019 & 29.000 & 143 & 48.000 & 232 \\
\hline
\end{tabular}

Sumber: Data Statistik Sukuk (OJK, 2019)

Sementara itu jika kita melihat perkembangan yang dipublikasikan oleh OJK, perkembangan sukuk masihlah sangat jauh dibandingkan dengan kompetitornya yaitu obligasi. Hal ini dapat dilihat dari nilai emisi sukuk korporasi dari lima tahun terakhir sangatlah jauh dengan nilai emisi dari obligasi korporasi. Hal ini terlihat dari gambar 1 tentang nilai emisi obligasi dan sukuk korporasi di Indonesia sepanjang tahun 2015 - 2019. 
Gambar 1.

Grafik Nilai Emisi Obligasi dan Sukuk Korporasi

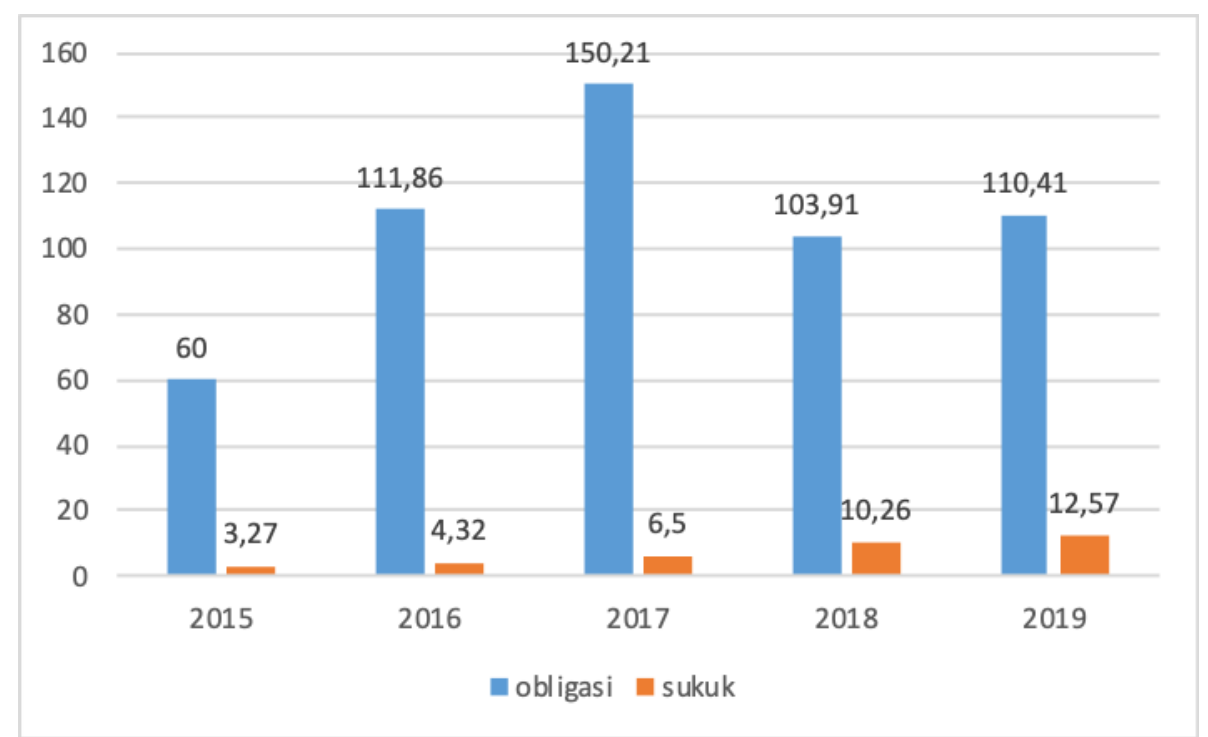

Sumber: Statistik Pasar Modal (OJK, 2019)

Gambar 1 memberikan gambaran bahwa dari tahun 2015 nilai emisi obligasi sebesar Rp. 60 Triliun sedangkan sukuk sebesar 3,27 Triliun. Pada tahun 2016 terjadi peningkatan yang tajam pada obligasi menjadi sebesar Rp. 111,86 Triliun sedangkan obligasi tidak terlalu signifikan kenaikannya dibandingkan tahun sebelumnya menjadi sebesar 4,32 Triliun. pada tahun 2017 nilai emsisi obligasi meningkat menjadi Rp 150,21 Triliun sedangkan sukuk meningkat menjadi Rp. 6,5 Triliun. Pada tahun 2018 pada obligasi mengalami penurunan menjadi Rp. 103,91 Triliun sedangkan sukuk mengalami peningkatan menjadi sebesar Rp. 10,2 Triliun. Pada tahun 2019 obligasi meningkat dari tahun sebelumnya menjadi sebesar Rp. 110,41 Triliun sedangkan sukuk korporasi tetap mengalami peningkatan dari tahun sebelumnya menjadi Rp. 12,57 Triliun. Dari data tersebut menunjukkan bahwa nilai emisi pada sukuk masihlah sangat jauh dibandingkan kompetitornya yaitu obligasi. Meskipun demikian dapat dilihat bahwa tren sukuk korporasi dari tahun ke tahun terus mengalami peningkatan dibandingkan obligasi yang sedikit berfluktuasi.

Sukuk sendiri memiliki berbagai jenis jika ditinjau dari segi akad baik itu ijarah, mudharabah, dan wakalah. Gambar 2 tentang nilai nominal sukuk per akad yang disajikan oleh OJK per Februari 2020 menunjukkan bahwa nilai nominal sukuk secara keseluruhan mencapai Rp. 29, 6 triliun. Adapun secara garis besar sukuk Mudharabah dominasinya urutan ke dua setelah sukuk ijarah yang paling mendominasi jenis penerbitannya dan sukuk wakalah diurutan ke tiga. Nilai nominal sukuk ijarah per Februari 2020 sekitar Rp.16 Triliun, Sukuk Mudharabah sekitar Rp. 11 Triliun, dan sukuk wakalah sebesar Rp. 1,45 Triliun. 


\section{Gambar 2.}

\section{Nilai Nominal Sukuk per Akad}

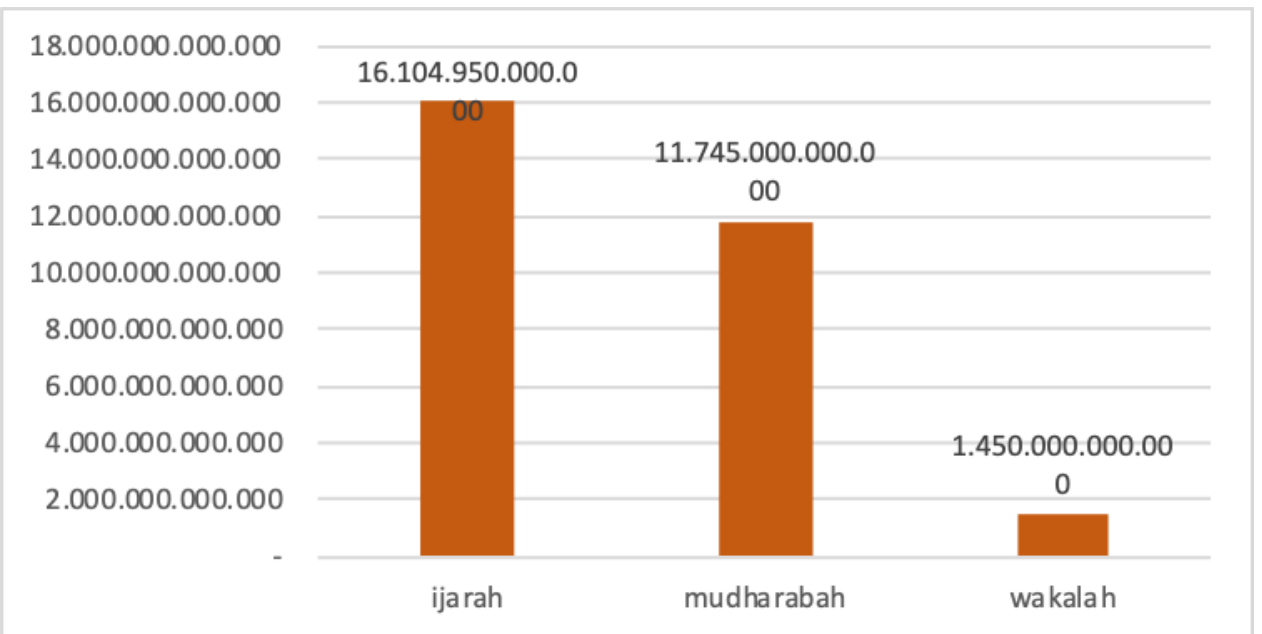

Sumber: Statistik Sukuk Korporasi (OJK, Februari2020)

Sukuk Mudharabah sendiri memiliki karakteristik yang berbeda dengan sukuk ijarah ataupun yang lainnya. Sisi keunikanya terletak pada nisbah dan bagi hasil pendapatan antara pemilik dana dan mudharib yang mana imbal hasil yang akan diterima bergantung kepada hasil usaha yang dilakukan oleh mudharib. Akad Mudharabah terlebih dahulu diaplikasikan oleh industri perbankan syariah baik itu dari sisi pendanaan maupun pembiayaan. Dalam dunia perbankan syariah produk berbasis Mudharabah memiliki resiko dimana ketika imbal hasil yang diberikan oleh bank syariah dibawah dari tingkat bunga dari bank konvensional maka ada indikasi nasabah akan mengalihkan dananya ke instrumen investasi lain yang lebih kompetitif atau resiko ini lebih dikenal dengan Displaced Commercial Risk (DCR). Oleh karena itu dirasa perlu untuk melihat apakah risiko ini juga berlaku pada sukuk Mudharabah yang notabene merupakan instrumen investasi bagi investor dan menjadi sumber modal bagi emiten. Melihat perkembangan sukuk yang mungkin masih dibawah jauh kompetitor utamanya membuat sukuk haruslah membuat berbagai inovasi sehingga dapat bersaing dengan obligasi. Paper ini akan fokus membahas beberapa hal berikut antara lain: pertama, implementasi dan implikasi akad Mudharabah dalam sukuk Mudharabab; Kedua, kemungkinan terjadinya Displaced Commercial Risk (DCR) dalam pelakasanaan sukuk Mudharabah; Ketiga, mengungkapkan adanya indikasi praktik Income Smoothing dalam sukuk Mudharabah Berkelanjutan I Sarana Multi Infrastruktur.

\section{LANDASAN TEORI}

Sukuk atau obligasi syariah merupakan efek syariah berupa sertifikat atau bukti kepemilikan yang bernilai sama dan mewakili bagian penyertaan yang tidak terpisahkan atau tidak terbagi atas kepemilikan asset berwujud tertentu, nilai manfaat dan jasa atas asset proyek tertentu atau aktifitas investasi tertentu, serta kepemilikan atas proyek tertentu atau aktivitas investasi tertentu (Soemitra, 2009). Fatwa Dewan Syariah Nasional No. 32/DSN-MUI/IX/2002 tentang Obligasi Syariah mendefinisikan obligasi syariah sebagai suatu surat berharga jangka panjang berdasarkan prinsip syariah yang dikeluarkan oleh emiten kepada pemegang obligasi syariah yang mewajibkan emiten untuk membayar pendapatan kepada pemegang obligasi syariah berupa bagi hasil/margin/fee, serta membayar kembali dana obligasi pada saat jatuh tempo. 
Penelitian tentang sukuk telah membagi ke dalam dua instrumen yaitu sukuk berbasis pertukaran (Exchange based sukuk) dan sukuk berbasis kemitraan (partnership sukuk). Exchange Based Sukuk merupakan sukuk yang melibatkan transfer aset dari penerbit sukuk ke investor sukuk dan akad yang digunakan dalam sukuk ini antara lain sukuk murababah, ijarah, bay' bithamanajil, ,musawamah, Bay' salam, Isthisna', Tawarruq, Bay' al-Inah. Sukuk berbasis kemitraan (partnership sukuk) adalah sukuk dimana investor menyuntikkan dana ke penerbit (emiten) dan mejadi mitra perusahaan dan akad yang digunakan adalah Mudharabah dan Musyarakah (Morni, 2019). Adapun pihak yang terlibat dalam penerbitan sukuk antara lain: emiten atau pihak yang menerbitkan sukuk dan bertanggung jawab kepada investor atas pembayaran pokok dan imbal hasil sukuk. Special Purpose Vehicle (SPV) yang merupakan badan khusus yang dibentuk dalam penerbitan sukuk yang berfungsi sebagai penerbit sukuk, Counterpart pemerintah dalam hal transaksi pengalihan asset, dan bertindak sebagai wali amanat yang mewakili kepentingan investor. Investor atau pihak yang memiliki sukuk dan berhak atas imbal hasil yang mana tergantung jenis sukuk, dapat berupa bagi hasil atupun margin. (Farisulhaq, et. al., 2019). Sukuk terbagi menjadi dua jenis jika dilihat dari institusi yang menerbitkan yaitu sukuk atau obligasi syariah korporasi yang diterbitkan oleh perusahaan dan sukuk atau obligasi syariah negara yang lebih dikenal dengan istilah surat berharga syariah negara (SBSN) (Soemitra, 2009).

Secara harfiah Mudharabah berasal dari kata dharb yang mempunyai arti memukul atau berjalan. Makna berjalan dan memukul pada pengertian ini lebih tepatnya adalah proses seseorang memukul kakinya dalam menjalankan usaha (Antonio, 2001). Dewan Syariah Nasional MUI mendefinisikan akad Mudharabah sebagai suatu bentuk perjanjian (akad) kerjasama suatu usaha antara pemilik modal (shohibul maal) dengan pengelola modal (mudharib). Shohibul maal merupakan pihak yang meneyediakan dana usaha sedangkan mudharib adalah pihak yang menjalankan usaha atau pengelola modal. Mudharabah atau bagi hasil merupakan salah satu bentuk bisnis yang digunakan oleh masyarakat arab lama untuk kegiatan perdagangan. Istilah dalam Mudharabah ada kalanya disebut dengan muqaradah yang mana istilah ini umum pada ulama Hanafiah dan qirad yang poopuler pada kalangan Hambali, Maliki, dan Syafi'i (Sapuan, 2016).

Obligasi syariah Mudharabah atau sukuk Mudharabab adalah surat berharga yang dikeluarkan oleh emiten atau pihak yang mengeluarkan sukuk baik pemerintah, perusahaan swasta, atau institusi lainnya yang di dalamnya memuat akad pembiayaan berdasarkan prinsip syariah yang mewajibkan emiten untuk membayar pendapatan kepada pemegang sukuk berupa bagi hasil dari pengelolaan dana serta mengembalikan kembali pokok dana saat jatuh tempo (Rahmawati dan Ghani, 2017). Dusuki (2010) menyebutkan Sukuk Mudharabah Merupakan sukuk yang berbasis ekuitas selain dari sukuk Musyarakah yang diterbitkan berbentuk kontrak partisipatif (Uqud al Muawanah). Dalam sukuk Mudharabah, pencetus atau emiten akan menjadi mitra pengelola usaha tanpa memberikan kontribusi modal apapun hanya keterampilan dan keahlian. Adapun landasan hukum atau regulasi sukuk dengan akad Mudharabah tertuang pada Fatwa Dewan Syariah Nasional MUI Nomor 33/DSN-MUI/XI/2002 tentang Obligasi syariah Mudharabah. .

Sukuk Mudharabah memiliki syarat dan rukun yang harus dipenuhi. Fadhilah (2011) menyebutkan terdapat tiga rukun dari sukuk Mudharabah antara lain al 'aqidayn atau pelaku yang berakad dalam hal ini emiten dan investor, ma'qud 'alayh yaitu modal, usaha, dan keuntungan, dan yang ketiga adalah shighat atau ijab dan kabul. Syarat-syarat yang ada pada akad Mudharabah antara lain kedua belah pihak yakni emiten dan investor haruslah terdapat pihak yang mampu untuk mewakilkan dalam hal ini pemilik sukuk atau wali amanat serta adanya pihak yang mampu menjadi wakil atau emiten. Selanjutnya yang terakhir adalah diantara kedua belah pihak diperbolehkan salah satunya berstatus kafir dzimmi, karena tidak disyaratkan bagi kedua belah pihak beragama Islam meskipun menurut Maliki hal ini dihukumi makruh.

Sukuk ini memberikan pemiliknya hak untuk menerima modalnya pada saat sukuk jatuh tempo, dan bagian tahunan dari laba yang direalisasi sebagaimana disebutkan dalam publikasi penerbitan. Sukuk dapat memainkan peran penting dalam proses pembiayaan pembangunan, karena terkait dengan profitabilitas proyek. Pembiayaan melalui Mudharabab lebih efisien dalam hal alokasi sumber daya dibandingkan dengan pembiayaan berdasarkan tingkat bunga, yang tidak 
mencerminkan profitabilitas proyek (Uddin, et al, 2016). Achyar (2018) menyebutkan sukuk Mudharabah mempunyai beberapa hal pokok diantaranya, kontrak haruslah tertuang pada perjanjian perwaliamanatan (trusty), nisbah atau rasio bagi hasil sukuk didasarkan pada pembagian pendapatan atau revenue sharing dan harus ditetapkan jelas dalam kontrak baik konstan, meningkat atupun menurun. Selanjutnya emiten membayar keuntungan atau tingkat pengembalian yang sesuai dengan yang tertera dalam kontrak bagi hasil dan dapat dilakukan secara periodik. Terakhir adalah sukuk jenis ini memberikan indikasi tingkat pengembalian hasil, hal ini dikarenakan besarnya pendapatan yang akan diterima didasarkan pada hasil kinerja aktual yang dilakukan oleh emiten. Rahman (2018) menyebutkan bahwa mudharib dalam hal ini adalah emiten tidak diperbolehkan untuk menjamin modal atau keuntungan dalam transaksi sukuk Mudharabah. Mudharib tidaklah bertanggung jawab atas kerugian yang terjadi kecuali karena kelalian, kesalahan manajemen dan ketidak jujuran yang menyebabkan kerugian, namun dalam hal ini pihak ketiga yang independen diperbolehkan memberikan jaminan untuk pengembalian modal.

\section{METODE PENELITIAN}

Metode penulisan yang digunakan dalam paper ini menggunakan penelitian kualitatif dalam bentuk riset kepustakaan atau library research dengan pendekatan kualitatif deskriptif dan (library research). Penelitian deskriptif merupakan metode penelitian yang bertujuan tuntuk menggambarkan fenomena-fenomena yang ada, yang sedang berlangsung saat ini maupun yang telah terjadi atau sudah lampau (Sukamadinata, 2012; dalam Fitrah dan Luthfiyah (2017)). Di paper ini tidak mengubah ataupun memanipulasi terhadap variabel-variabel bebas, namun menggambarkan kondisi apa adanya baik secara individual maupun menggunakan angka-angka. Obyek dalam penelitian ini adalah Sukuk Mudharabah Berkelanjutan I Sarana Multi Infrastruktur. Adapun data yang digunakan dalam penelitian ini merupakan data sekunder yang bersumber dari jurnal, artikel, maupun referensi lain yang relevan dengan topik penelitian. Selain itu data juga berupa prospektus Sukuk Mudharabah Berkelanjutan I Sarana Multi Infrastruktur yang dikeluarkan oleh PT Sarana Muti Infrastrutur (Persero). Selanjutnya dalam peneltian ini penulis melakukan pengamatan dan telaah prospektus guna mengamati potensi adanya DCR dalam sukuk mudharabah dan praktik Income Smoothing yang terjadi dalam sukuk Mudharabah PT SMI dengan menggunakan pendekatan fakta dan juga menggunakan berbagai literatur dan jurnal yang relevan dalam melakukan observasi serta analisisnya. Dipilihnya Sukuk Mudharabah berkelanjutan I PT SMI dikarenakan sukuk ini salah satu yang terbesar dengan nilai nominal sebesar satu triliun rupiah. Selain itu pada PT SMI terdapat unit usaha syariah dalam kegiatan usahanya.

\section{HASIL DAN PEMBAHASAN}

PT Sarana Multi Infrastruktur atau PT SMI merupakan Badan Usaha Milik Negara yang bergerak di bidang infrastruktur. PT SMI didirikan pada tanggal 26 Februari 2009 yang seluruh modal sahamnya dikuasia oleh Negara melalui Kementerian Keuangan. Sektor infrastruktur dasar yang dibiayai oleh PT SMI antara lain ketenagalistrikan, transportasi, telekomunikasi, rolling stock kereta api, minyak dan gas, energi efisien, air minum, jalan dan jembatan, serta manajemen air limbah dan persampahan. Adapun pembiayaan yang dilakukkan pada sektor infrastruktur sosial antara lain rumah sakit, infrastruktur pemasyarakatan, infrastruktur pendidikan, infrastruktur kawasan, pasar, dan infrastruktur pariwisata. Kinerja PT SMI berdasarkan laporan yang tertuang dalam prospektus pada akhir tahun 2017 atau 31 Desember 2017 pendapatan usaha perseroan mengalami peningkatan 35,43\% atau sebesar Rp. 825.419 juta menjadi Rp. 3.154.863 juta. Jika dibandingkan dengan akhir tahun 2016 atau 31 Desember 2016 peningkatan ini disebabkan terutamanya pada peningkatan bunga atas pinjaman yang diberikan sebesar Rp. 933.639 juta yang sejalan dengan peningkata posisi pinjaman diberikan pada 31 Desember 2017. 
Sukuk Mudharabah diterbitkan oleh PT SMI yang mana tujuan dari penerbitan ini sebagaiaman dijelaskan dalam prospektus yaitu dana sukuk akan digunakan untuk penyaluran kegiatan pembiayaan syariah melalui unit usaha syariah, investasi syariah serta kegiatan jasa konsultasi dan penyiapan proyek oleh perseroan dalam hal ini adalah kegiatan usaha perseroan. Sementara itu secara ringkas skema sukuk Mudharabah dapat dilihat dari bagan dibawah ini:

Gambar 3. Skema sukuk PT SMI

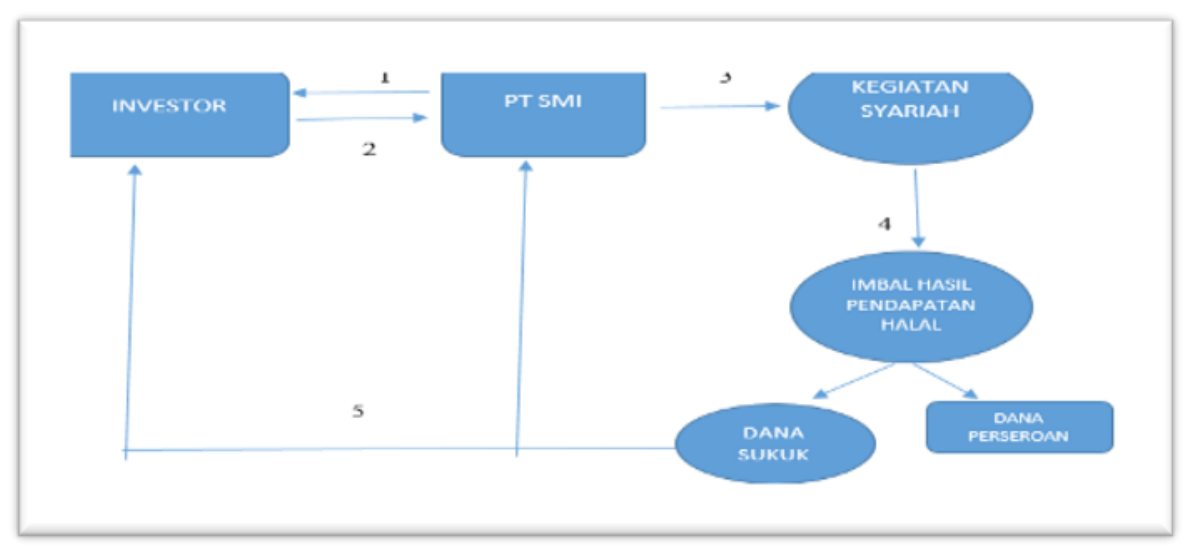

Sukuk Mudharabah diterbitkan oleh PT SMI dengan nominal satu triliun rupiah dan disaat bersamaan investor menyerahkan dananya sebesar nilai sukuk pada PT SMI. Penggunaan dana hasil emisi sukuk diperuntukkan pada pembiayaan syariah, investasi syariah oleh unit usaha syariah, serta kegaiatan jasa konsultasi dan penyiapan proyek oleh perseroan. Selanjutnya pendapatan yang diperoleh dari hasil kegiatan tersebut didistribusikan secara proporsional kepada setiap sumber pendanaan yang berasal dari sukuk dan dana perseroan. Pendapatan dari kegiatan usaha tersebut yang menjadi porsi dana sukuk Mudharabah dibagi hasilkan antara investor dan perseroan melalui unit usaha syariah sesuai dengan nisbah yang ditentukan atau disepakati sebelumnya. Selanjutnya, para akhir jangka waktu sukuk, perseroan akan mengembalikan pokok dana sukuk kepada investor pada saat jatuh tempo investasi.

\section{Implementasi Akad Mudharabah Dalam Sukuk Mudharabah PT SMI}

Akad Mudharabah mempunyai beberapa syarat dan rukun dalam pelaksanaannya. Kegiatan transaksi apapun yang menggunakan akad Mudharabah haruslah memenuhi syarat dan rukun akad Mudharabah sehingga transaksi tersebut dapat dikatakan transaksi atau kontrak Mudharabah. Sukuk Mudharabah yang dinamakan shohibul maal adalah investor pemegang sukuk Mudharabah, sedangkan yang dinamakan mudharib adalah emiten atau penerbit sukuk. Sementara itu perjanjian akad Mudharabah tertuang pada porspektus yang dikeluarkan oleh emiten dan investor jika setuju dengan isi porspektus tersebut akan membeli sukuk Mudharabah tersebut.

Shobibul maal dalam hal ini investor membeli sukuk Mudharabah yang mana artinya adalah mengikutsertakan dananya pada Mudharib atau emiten dalam hal ini adalah PT SMI dalam mengembangkan bisnis syariah. Nisbah bagi hasil yang diberikan oleh mudharib atau emiten sebesar $14,31 \%$ untuk investor atau shabibul maal pada sukuk Mudharabah seri A dan 6,96\% untuk sukuk Mudharabah seri B. Proses pembelian sukuk ini merupakan bagian dari akad Mudharabah, yang mana saling pihak sama-sama rela perihal yang di akadkan. Penjabaran dalam porspektus tersebut sudah termuat beberapa poin mengenai dana Mudharabah yang akan digunakan untuk usaha seperti apa yang akan dilakukan. Selanjutnya, pada Sukuk Mudharabah Berkelanjutan I Sarana Multi Infrastruktur ini dana yang diperoleh dari sukuk akan digunakan untuk pengembangan usaha syariah. Sebagaimana diketahui bahwa PT SMI memiliki produk pembiayan berbasis syariah 
diantaranya pembiayaan Ijarah Muntahiyah Bit Tamlik (IMBT), pembiayaan Murabahah, dan Pembiayaan Musyarakah Mutanaqisah (MMQ)

Ciri utama dalam akad Mudharabah adalah nisbah bagi hasil yang akan mengimplementasikan jumlah pendapatan yang akan dibagikan antara pemilik dana dan mudharib. Nisbah ini merupakan suatu yang sangat pokok yang harus ada pada akad Mudharabah dan penentuan nisbah harus melalui kesepakatan antar pihak, baik itu shabibul maal maupun mudharib. Ketentuan mengenai nisbah dalam porspektus Sukuk Mudharabah Berkelanjutan I Sarana Multi Infrastruktur dijelaskan bahwa bagi hasil untuk investor pada seri A sebesar 14,31\% dan 6,96\% untuk seri B yang dihitung dari pendapatan yang dibagi hasilkan dengan menggunakan rata-rata tingkat imbal hasil (rate) efektif pembiyaan sebesar 7,55\% untuk seri A dan 7,80\% untuk seri B.

Penjelasan di atas menunjukkan bahwa secara umum syarat dan ketentuan dari akad Mudharabah yang diaplikasikan pada sukuk Mudharabah telah terpenuhi syarat dan rukunnya. Dalam masalah skema akad Mudharabah dalam sukuk Mudharabah ini dapat dikatan sesuai dengan ketentuan yang ada atau sesuai dengan syariah. Namun terdapat salah satu rukun dari Mudharabah yang tidak dapat diterapkan dalam produk ini yaitu jika mengalami kerugian maka akan ditanggung sepenuhnya oleh pemodal, mudharib pun mengalami kerugian meskipun bukan dari segi modal melainkan dari hasil kerjanya.

Hal tersebut dapat ditemukan dalam penjelasan yang tertera dalam prospektus sebagai berikut: "Menerima pelunasan dana sukuk. Mudharabah dan/atau pembayaran pendapatan bagi hasil sukuk. Mudharabah dari perseroan pada tanggal pembayaran kembali dana sukuk. Mudharabah dan/atau tanggal pembayaran pendapatan bagi hasil sukuk. Mudharabah yang bersangkutan."

Penjelasan tersebut secara jelas bahwa salah satu hak pemegang sukuk ialah dikembalikannya modal yang ditanamkan oleh investor. Hal ini mengindikasikan bahwa emiten mempunyai kewajiban untuk mengembalikan modal secara utuh kepada investor. Alimin (2013) mengutip pendapat dari Abu Bakar (1998) mengemukakan bahwa para fuqoha sepakat sepakat bahwa modal akan diserahkan sesuai dengan nilai semula, misal jika modal awal Rp. 100 Milyar maka harus dikembalikan oleh mudharib sebesar Rp. 100 Milyar saat jatuh tempo. Akan tetapi jika modal berkurang pada saat akad berakhir atau jatuh tempo yang diakibatkan oleh resiko bisnis bukan kesalahan mudharib, maka mudharib tidak bertanggung jawab atas hal tersebut. Namun, jika berkurangnya karena kelalaian mudharib, maka mudharib wajib bertanggung jawab akan modal shobibul maal. Jika syarat pengembalian modal tersebut tetap disertakan dalam akad, maka akad tersebut menjadi rusak atau tidak boleh dilaksanakan menurut ulama Hanafi dan Hanbali, dan batal menurut ulama Maliki dan Syafi'i.

Penjelasan yang terdapat dalam porspektus di atas secara jelas menyebutkan bahwa salah satu hak dari shobibul maal adalah menerima pelunasan dana sukuk Mudharabah atau modal yang ditanamkan oleh investor. Hal ini sebenarnya tidaklah dapat dibenarkan oleh fikih karena berlawanan dengan substansi akad Mudharabah yang mana investor tidak berhak memaksa mudharib untuk melakukan sesuatu diluar kemampuannya kecuali memang terjadi kelalaian atau wanprestasi (Alimin, 2013) .

Permasalahan mengenai jaminan modal memang menjadi sebuah problem dalam sukuk Mudharabah. Lahsana dan Lin (2012) menyebutkan bahwa putusan dari International Fiqh Academy's menyatakan baik prospektus maupun perbuatan Muqaradha (Mudharabah) tidak boleh mengandung jaminan dari manajer dana untuk modal atau laba tetap berdasarkan persentase modal. Modal diperbolehkan dijamin oleh pihak ketiga yang sama sekali tidak terkait dengan kedua belah pihak, serta tidak diperbolehkan menjadi sebuah penentu keterlangsungan kontrak. Sapuan (2016) menyebutkan para sarjana kontemporer meyetujui akan adanya jaminan pengembalian modal Mudharabah dari pihak ketiga baik itu dari pihak pemerintah maupun pihak swasta. Perihal pendanaan Mudharabah pada perbankan syariah baik berupa tabungan, giro, maupun deposito Mudharabah dilindungi oleh Lembaga Penjamin Simpanan. Hal ini mengindikasikan bahwa Shobibul Maal dalam hal ini nasabah yang menanamkan dananya pada perbankan terjamin akan keutuhan akan pokok dan bagi hasilnya dengan jumlah maksimal Rp. 2 Milyar. Selain itu dalam Fatwa Dewan Syariah Nasional No. 105/DSN-MUI/X/2016 tentang Penjaminan Pengembalian Modal 
Pembiayaan Mudharabah, Musyarakah, dan Wakalah bil Istitsmar khususnya pada sub bab ketentuan khusus yang dijelaskan pada poin kedua bahwa pengelola modal diperbolehkan menjamin akan pengembalian modal atas kehendaknya sendiri tanpa permintaan dari pemilik modal. Landasan dari fatwa DSN tersebut yang menurut penulis menjadi acuan akad pengembalian modal oleh emiten kepada investor pada sukuk Mudharabah PT SMI.

\section{Indikasi Displaced Commercial Risk (DCR) dalam sukuk Mudharabah}

Akad Mudharabah merupakan suatu bentuk kerjasama yang mengedepankan unsur kepercayaan antar pihak dalam menjalankan suatu usaha. Akad Mudharabah memiliki ciri khusus yang menjadi pembeda dari sebuah kontrak kerja sama konvensional lainnya yaitu penggunaan bagi hasil. Dunia perbankan syariah prinsip bagi hasil merupakan suatu landasan operasional terhadap produk pembiayaan Mudharabah dan Musyarakah yang mana prinsip ini merupakan sebuah pembeda dari kompetitornya yaitu perbankan konvensional. Sistem bagi hasil sendiri dapat berupa profit sharing dan revenue sharing (Muhamad, 2004). Penerapan akan prinsip bagi hasil tersebut dengan sifat perbankan sendiri yang mempunyai unsur modal dari dana pihak ke tiga otomatis membuat perbankan syariah memiliki sebuah risiko khusus yaitu Displaced Commercial Risk (DCR), kondisi ini ketika imbal hasil dari usaha tersebut turun sehingga memepengaruhi prilaku para nasabah. (Solisa, 2017). Adiwarman (2001) sebagaimana disebutkan oleh Yahya, et. al. (2011), dalam skema bagi hasil tidaklah terdapat suatu fixed and certain return (tetap dan pasti kembali) seperti halnya bunga, namun dilakukan profit and loss sharing yang didasarkan oleh produktifitas nyata dari suatu produk. Oleh karena itu perbankan syariah mempunyai resiko tersendiri yaitu potensi adanya fund flight yang timbul akibat kurang bersaingnya rate of return (tingkat imbal hasil) perbankan syariah terhadap perbankan konvensional atau instrumen investasi lainnya.

Melihat penerapan akad Mudharabah pada perbankan syariah memang mempunyai sebuah resiko DCR yang muncul dari risiko imbal hasil. Risiko imbal hasil sendiri diakibatkan karena terjadi perubahan tingkat imbal hasil yang diperoleh bank dari pembiayaan atau penyaluran dana sehingga imbal hasil yang disalurkan kepada nasabah terjadi perubahan sehingga dapat mempengaruhi perilaku nasabah dana pihak ketiga (Fasa, 2016). Adanya risiko DCR ini memang membuat simpanan Mudharabah diperlakukan sama seperti halnya simpanan di bank konvensional. Hal ini dikarenakan jika bank menerapkan sistem bagi hasil murni yang mempunyai resiko tinggi dalam produknya sehingga ketika bank konvensioal dapat memberikan rate yang lebih tinggi maka akan terjadi pemindahan dana ke bank kovensional. Situasi tersebut bisa terjadi karena nasabah bersikap rasional dengan memilih menabung pada bank yang memberikan yang tinggi baginya (Pramananda, 2014). Dunia pasar modal sendiri memang isu akan adanya Displaced Commercial Risk (DCR) hampir tidak ditemukan akan adanya penelitian menyangkut isu tersebut. Hal ini dikarenakan sifat risiko tersebut berbeda antara perbankan dan pasar modal khusunya obligasi atau sukuk. Sementara itu dalam perbankan syariah akibat dari risiko tersebut sangatlah cepat karena sifatnya yang sangat likuid terlebih pada tabungan dan deposito yang sudah jatuh tempo. Berbeda halnya ketika investor terlanjur membeli sukuk atau obligasi maka untuk melikuidasi sukuk tersebut membutuhkan mekanisme yang tidak sederhana. Hal ini dikarenakan dalam sukuk atupun obligasi terdapat risiko likuiditas yang mana risiko ini ketika investor kesulitan dalam pencairan. Risiko yang dapat terjadi adalah investor terpaksa menjual kepada agen penjual dibawah harga pasar atau dalam kata lain obligasi atau sukuk akan terjual dengan harga diskon (Meirinaldi dan Astuti, 2017).

Penjelasan di atas secara aplikasi indikasi DCR berbeda apa yang terjadi dalam perbankan syariah dan dunia pasar modal terutama obligasi atau sukuk. Pada perbankan resiko tersebut hadir ketika posisi uang atau modal yang dari investor sudah berada di Bank dalam bentuk tabungan ataupun deposito. Sementara itu penulis juga melihat adanya indikasi Displaced Commercial Risk (DCR) namun sebelum modal dari investor berada pada emiten yakni ketika investor akan memutuskan portofolio investasinya. Hal ini merupakan sebuah hal yang wajar karena pada dasarnya seorang investor sebelum melakukan investasi akan memperhitungkan risiko dan Pengembalian. Investor akan memilih satu atau beberapa kombinasi investasi dengan berharap mendapatkan sejumlah return atau pendapatan di masa yang akan datang (Widayat, 2010). Dewi 
(2011) menyebutkan bahwa salah satu problem investor yang menyebabkan rendahnya tingkat perkembangan sukuk di Indonesia yaitu investor bersikap averse to risk atau enggan menghadapi risiko. Risiko yang dimaksud disini salah satunya adalah risiko pengembalian pada sukuk Mudharabah yang bergantung pada kinerja perusahaan. Sartono (2001) menyatakan bahwa asumsi seorang individu dalam menyikapi risiko dan tingkat keuntungan yang diharapkan adalah individu bersikap rasional dan tidak menyukai risiko atau risk averse. Sikap ini tercermin dari sikap investor yang menginginkan tambahan keuntungan dari yang lebih besar dari setiap kenaikan resiko yang dihadapi. Atau dengan kata lain misalkan individu dihadapkan oleh sebuah pilihan maka individu tersebut akan lebih memilih untuk memperoleh tingkat keuntungan yang sama dan resiko yang lebih kecil.

Penelitian mengenai isu tentang sukuk Mudharabah yang mungkin dilakukan oleh lembaga non bank telah dilakukan oleh beberapa peneliti. Pertama, penelitian dari Mutia, et al (2018) membandingkan antara kinerja pasar sukuk ijarah dan Mudharabah. Hasil penelitian ini menunjukkan bahwa sukuk ijarah dapat meminimalkan potensi dampak negatif karena perubahan kondisi pasar pada aset dan investasi modal. Penelitian ini menyimpulkan bahwa risiko investasi pada sukuk Ijarah lebih rendah dari sukuk Mudharabah. Febriani dan Mala (2013) dalam penelitiannya menyimpulkan bahwa suku bunga simpanan perbankan mempunyai hubungan yang positif dan signifikan terhadap imbal hasil sukuk Mudharabah. Hal ini mengindikasikan bahwa emiten selaku penerbit sukuk meningkatkan imbal hasil sukuk agar menarik pada pasar sekunder. Penelitian ini menunjukkan bahwa investor tidaklah hanya memandang aspek kesyariahan saja, melainkan investor juga bersifat rasional dalam menentukan investasinya. Nasrullah, et al (2013) dalam hasil penelitiannya juga menemukan tidak hanya dari aspek kepatuhan syariah saja yang berpengaruh terhadap minat investor pada sukuk negara, melainkan yang paling dominan adalah manfaat dari suku bunga. Hasil penemuan ini menggambarkan bahwa variabel spekulasi merupakan variabel yang paling berpengaruh terhadap tingginya tingkat pembelian sukuk negara.

Berdasarkan penjelasan di atas, maka dapat ditarik kesimpulan bahwa di dalam sukuk Mudharabah terdapat indikasi adanya Displaced Commercial Risk (DCR). Adapun implikasi dari adanya DCR ini timbul saat investor menentukan portofolio investasinya artinya sukuk Mudharabah tidak laku atau tidak terjual. Investor tidak hanya memandang aspek syariah, namun Investor akan cenderung bersikap rasional dalam menentukan portofolio investasinya di mana investasi yang menghasilkan pengembalian yang lebih pasti dan risiko yang rendah akan dipilih oleh investor. Oleh karena itu diperlukan adanya mitigasi akan risiko dari adanya risiko ini terutama pada aspek pengembalian atau bagi hasilnya.

Displaced Commercial Risk (DCR) sendiri di dalam Lembaga Keuangan Syariah (LKS) disikapi atau secara aturan syariah terdapat dalam Fatwa Dewan Syariah Nasional No. 87/DSNMUI/XII/2012 Tentang Metode Perataan Penghasilan (Income Smoothing) Dana Pihak Ketiga. Berdasarkan fatwa tersebut perbankan syariah dapat menerapkan dua cara dalam mengatasi akan adanya resiko DCR, yaitu dengan menerapkan Income Smoothing dengan mitigasi atau Profit Equalization Ratio (PER) dan Income Smoothing tanpa mitigasi (Isqath al-haqq/ at-tanazul 'an al-haqq). Profit Equalization Ratio (PER) atau metode perataan penghasilan dengan membetuk dana cadangan merupakan pengaturan distribusi keuntungan dari waktu ke waktu atas bagi hasil antara Lembaga Keuangan Syariah (LKS) dan nasabah penyimpan dana dengan cara membentuk cadangan perataan laba/penghasilan. Metode Income Smoothing tanpa membentuk cadangan atau tanpa mitigasi adalah pengaturan pengakuan dan pelaporan laba dari waktu ke waktu untuk tujuan pengaturan bagi hasil antara Lembaga Keuangan Syariah (LKS) dan Nasabah tanpa membentuk cadangan.

\section{Indikasi Tanazul atau Income Smoothing dalam sukuk Mudharabah PT SMI}

Investor sebelum memutuskan di mana uangnya akan diinvestasikan tentu saja akan mempelajari dulu informasi-informasi yang berhubungan dengan objek investasinya. Perihal sukuk dan juga obligasi salah satu informasi yang digunakan oleh investor adalah dari prospektus produk tersebut. Prospektus Sukuk Mudharabah PT SMI menjelaskan mengenai nisbah bagi hasil yang 
akan diterima oleh investor dan juga beberapa informasi lainnya yang berkenaan dengan kepentingan investor. Redaksi yang terdapat prospektus tersebut terdapat sebuah penjelasan mengenai adanya upaya meratakan pendapatan ketika terjadi penurunan atau kenaikan dalam pendapatan bagi hasil pada pemegang sukuk:

Dalam hal pendapatan bagi hasilyang diterima oleh pemegang sukuk. Mudharabah mengalami penurunan, maka perseroan akan memberikan sebagian porsinya untuk pemegang sukuk. Mudharabah, sehingga pemegang sukuk Mudharabah seri $A$ dan seri $B$ akan menerima pendapatan bagi hasil sesuai denga batas nila minimal 7,50\% (tujub koma lima pulub persen) untuk seri $A$ dan $7,75 \%$ (tujub koma tujub lima persen) untuk seri $B$.

Apabila pendapatan bagi hasil yang diterima oleh pemegang sukuk. Mudharabah mengalami peningkatan, maka pemegang sukuk. Mudharabah masing-masing seri A dan seri B mengikblaskan sebagian porsinya untuk perseroan, sehingga perseroan akan melaksanakan kewajibannya membayar pendapatan bagi hasil kepada pemegang sukuk. Mudharabah masing-masing seri $A$ dan seri $B$ sesuai dengan batas maksimal 7,60 \% (tujub koma enam nol persen) dan 7,85\% (tujuh koma delapan lima persen) untuk seri $B$.

Penjelasan dari porspektus di atas menyimpulkan bahwa ketika suatu usaha yang dilakukan oleh emiten mengalami penurunan pendapatan sehingga yang dibagihasilkan kepada investor mengalami penurunan, maka emiten akan menutupi kekurangan tersebut sampai batas minimal penurunan pengembalian sebesar 7,50\% untuk seri A dan 7,75\% untuk seri B. Begitu pula ketika usaha yang dilakukan oleh emiten mengalami keuntungan yang meningkat sehingga yang dibagi hasilkan kepada nasabah lebih banyak, maka emiten hanya akan memberikan kelebihan sebesar 7,60\% untuk seri A dan 7,85\% untuk seri B dan sisanya diikhlaskan untuk emiten. Jika hal tersebut dipahami demikian maka yang terjadi disini adalah permintaan pasar yang menginginkan pendapatan tetap. Memang dalam penjelasan dari porspektus tersebut tidaklah disebutkan nominal tetap yang akan diterima oleh nasabah, namun penggalan tersebut dapatlah dipahami bahwa dalam akad Mudharabab ini pendapatan tetap lebih diinginkan dari pada pendapatan bagi hasil. Pendapatan tetap tentunya bukanlah sebuah prinsip dari akad bagi hasil atau Mudharabah.

Hal ini sesuai dengan penelitian yang dilakukan oleh Alimin (2013) yang mana dalam penelitiannya menemukan hampir terdapat pada semua klausula yang ditelitinya. Alimin (2013) berpendapat bahwa jika terdapat klausula yang berkaitan dengan kelebihan dan kekurangan dari tingkat laba yang diharapakan yang mana ketika kekurangan akan ditutupi oleh obligor atau emiten sedangkan jika terjadi kelebihan menjadi intensif bagi obligor atau emiten, maka yang diinginkan adalah laba tetap atau jumlah nominal tetap bagi shobibul maal atau investor. Lebih lanjut lagi Alimin (2013) berpendapat jika hal ini diterapkan maka hal ini berlawanan dengan tuntutan akad (muqtadha al-'aqd), yang akhirnya menihilkan substansi akad bagi hasil dan menjadi akad ribawi.

Konsekuensi logis dari akad Mudharabah adalah bagi hasil dan bagi rugi yang masuk dalam kontrak investasi. Jika investasi yang dijalankan menghasilkan laba besar, maka keuntungan yang dibagihasilkan juga besar pula dan begitu juga sebaliknya. Filosofi ini hanya bisa terjadi dalam bentuk prosentase bukan nominal (Karim, 2013). Namun, sebagaimana yang dijelaskan dalam porspektus tersebut sebenarnya terdapat nominal yang disembunyikan. Batasan prosentase ini mengandung angka nominal tetap bagi hasil yang akan dibagikan kepada nasabah. Oleh karenanya penulis menilai terdapat batasan keuntungan dan kerugian yang akan ditanggung oleh shohibul maal atau bahkan tidak mengandung kerugian sama sekali.

Penjabaran dalam prospektus yang menjelaskan bahwa jika pendapatan yang diperoleh melebihi tingkatan yang ada maka pemegang sukuk akan mengikhlaskan untuk perseroan atau emiten merupakan aplikasi dari isu tanazul dalam sukuk. Tanazul sendiri adalah sebuah tindakan untuk melepas hak-hak klaim tertentu yang menguntungkan pihak lain dalam kontrak. Aplikasi dalam keuangan Islam biasanya tanazul diterapkan dimana hak untuk berbagi sebagian dari keuntungan diberikan kepada orang lain (Elias, et al, 2013). Noor dan Haron (2015) mengemukakan isu tanazul dalam sukuk Mudharabah ketika penerbit memasukkan syarat yang menyebutkan jika keuntungan yang sebenarnya melebihi tingkatan tertentu maka jumlah atau kelebihan itu diberikan kepada penerbit sukuk atau mudharib sebagai intensif dikarenakan 
pengelolaan yang baik. Selanjutnya penyedia modal atau shobibul maal menepikan haknya untuk menuntut jumlah yang melebihi keuntungan yang diharapkan.

Berdasarkan dari berbagai pejelasan yang tertuang di atas, bahwa indikasi tanazul dalam praktik sukuk Mudharabah PT SMI antara lain aturan mengenai batas bawah dan batas atas keuntungan yang akan di berikan oleh investor. Selain itu indikasi yang lain adalah pemberian hak lebih kepada emiten ketika pendapatan investor melebihi batas atas tersebut. Mengenai adanya batas atas dan batas bawah pendapatan yang akan diterima oleh investor merupakan bentuk dari pemerataan penghasilan kepada pemegang sukuk atau investor. Indikasi tersebut menegaskan bahwa investor akan mendapatkan pengembalian bagi hasil paling sedikit sebesar 7,50\% untuk seri A dan 7,75\% untuk seri B dan dan paling banyak sebesar 7,60\% untuk seri A dan 7,85 dari seri B dari indikatif rate sebesar 7,55\% untuk seri A dan 7,80\% untuk seri B. Hal ini mengindikasikan bahwa yang akan terjadi dalam sukuk mudhrabah ini adalah condong kepada fixed return atau pendapatan tetap plus minus sebesar 5\% (lima persen) dari indikatif ratenya. Indikasi tanazul selanjutnya adalah berkenaan dengan intensif yang menjadi hak emiten ketika pendapatan yang diterima investor melebihi batas atas yaitu sebesar 7,60\% untuk seri A dan 7,85 dari seri B.

Penjelasan di atas merupakan suatu bentuk dari Income Smoothing atau perataan penghasilan. Adapun yang terdapat dalam penjelasan tersebut tidak dikemukakan mengenai adanya cadangan akan keuntungan melainkan penjelasan tersebut terdapat kata "Dalam hal pendapatan bagi hasil yang diterima oleh pemegang sukuk. Mudharabah mengalami penurunan, maka perseroan akan memberikan sebagian porsinya untuk pemegang sukuk" dan "Apabila pendapatan bagi hasil yang diterima oleh pemegang sukuk. Mudharabah mengalami peningkatan," yang mana hal ini mengindikasikan bahwa perataan pendapatan terjadi ketika disaat terjadi penurunan dan peningkatan pendapatan kurang atau lebih dari $5 \%$ dari indikatif ratenya. Hal ini mengindikasikan perataan pendapatan dalam sukuk Mudharabah terjadi tanpa adanya cadangan atau mitigasi atau Income Smoothing tanpa mitigasi. AAOIFI dalam Noor dan Haron (2015) membenarkan akan perjanjian seperti ini, AAOIFI menyatakan dalam standar syariah Mudharabah sebagai berikut:

"Tika salah satu dari kedua belah pibak harus menentukan untuk memiliki jumlab tertentu (laba), mudarabah akan batal. Namun, larangan ini tidak termasuk dalam perjanjian yang dibuat oleh kedua belah pibak babwa jika keuntungan melebihi persentase tertentu maka salah satu dari keduanya para pibak akan menerima surplus dan distribusi akan sesuai dengan keduanya."

Pendapat dari AAOIFI tersebut menjadi dasar akan dibolehkannya tanazul dalam sukuk Mudharabah. Hal ini sama dengan apa yang berada dalam ketentuan dari sukuk Mudharabah PT SMI. Dengan adanya konsep ini maka secara jelas terdapat mekanisme perataan pendapatan yang akan diberikan oleh emiten kepada investor atau income smoothing.

Penjelasan di atas menyimpulkan memang terjadi perataan penghasilan dalam sukuk Mudharabah PT SMI. Memang tidak bisa dipungkiri hal ini merupakan suatu yang amat jauh dari nilai Mudharabah yang memegang akan prinsip bagi hasil. Alimin (2013) menganggap hal ini sudah keluar dari tuntutan akad (muqtadha al-'aqd), yang akhirnya menihilkan substansi akad bagi hasil dan menjadi akad ribawi. Dusuki (2010) juga menyimpulkan bahwa hal ini menyerupai dengan fitur yang ada dalam obligasi konvensional. Hal ini mengindikasikan inovasi tersebut bertujuan untuk mencapai hasil ekonomi yang sama dengan obligasi konvensional dan hal ini tidak seusai dengan Maqashid as syariah. Pendapat ini memperkuat argumentasi dari Syekh Taqi Usmani pada bulan November 2007 yang menyatakan sebagian besar atau sekitar 85\% sukuk di sektor bisnis yang menggunakan struktur Musharakah atau Mudharabah tidak sesuai dengan standar syariah (Zadeh, 2016).

\section{PENUTUP}

Sukuk Mudharabah dengan konsep murni bagi hasil otomatis akan menghadapi problem ketidakpastian yang besar dari sisi pengembalian. Hal ini dikarenakan sifat asli dari Mudharabah yang menerapkan sistem bagi hasil yang bergantung pada kondisi usaha mudharib atau emiten. Fenomena 
ini akan menyebabkan sukuk Mudharabah akan kurang menarik dimata investor sehingga kemungkinan sukuk Mudharabah tidak laku di pasar dikarenakan investor akan bersikap realistis dan cenderung menghindari resiko sehingga investor akan mencari portofolio investasi yang lain. Tujuan dalam paper ini untuk mengetahui potensi DCR dalam sukuk mudharabah dan praktik income smoothing pada Sukuk Mudharabah Berkelanjutan I Sarana Multi Infrastruktur. Hasil pengamatan dan telaah pustaka dalam paper ini menemukan adanya potensi akan (DCR pada sukuk mudharabah secara umum. Selain itu juga terdapat praktik income smoothing yang terjadi pada Sukuk Mudharabah Berkelanjutan I Sarana Multi Infrastruktur.

Income smoothing menjadi upaya yang dilakukan untuk menjaga kemungkinan adanya penurunan bagi hasil yang diterima oleh nasabah pemegang sukuk sehingga mengurangi kemungkinan adanya DCR. Namun demikian, dari sudut pandang syariah hal ini tentu menjadi suatu masalah yang cukup krusial mengingat akad Mudharabah menggunakan ketentuan dasar bagi hasil, baik menggunakan dasar revenue sharing ataupun profit loss sharing. Konsep sharing membawa konsep dimana adanya upaya natural untuk mengedepankan mekanisme pasar untuk mendapatkan hasil dari suatu upaya tertentu sehingga membedakan dengan pendekatan bunga, sebagai bentuk hasil nominal yang ditetapkan di awal kesepatakan. Maka dari itu, regulator perlu melakukan telaah terkait dengan praktik dan implikasi dari pelaksanaan income smoothing yang terjadi dalam implementasi produk Sukuk Mudharabah. Telaah menjadi penting untuk melihat kecenderungan praktik income smoothing ini sebagai bentuk upaya menyederhanakan penjualan produk atau bentuk penyimpangan dalam kontrak. Diharapkan ke depan produk dan jasa di industri keuangan syariah tidak sekedar mendapatkan legalisasi dalam bentuk fatwa namun juga perlu dikaji lagi implikasinya terhadap perilaku masyarakat yang menggunakan produk dan jasa keuangan syariah.

\section{DAFTAR PUSTAKA}

Achyar, M. (2018). Sukuk: Instrumen Pembiayaan Islami Potensial. Labatila: Jurnal Ilmu Ekonomi Islam, Vol. 2, No. 1.

Antonio, M. S. (2001). Bank Syariah Dari Teori Ke Praktik. Jakarta: Gema Insani

Alimin. (2013). Sukuk Mudharabah Sebagai Instrumen Keuangan Islam Ideal Kontemporer. AlQalam. Vol. 30, No.1 Januari-April 2013

Dewi, N. (2011). Mengurai Masalah Pengembangan Sukuk Korporasi Indonesia Menggunakan Analytic Network Process. Tazkia Islamic Finance \& Business Review, Vol. 6, Agustus 2011.

Dusuki, A. W. (2010). Do equity-Based Sukuk Strucures Fulfill the Objectives of Shari'ah (Maqasid al-Shariah). Review of Islamic Economics, Vol. 14, No.2.

Elias, M. R. F., Nasir, M., \& Mohd Faysal, M . (2013). Shariah Issues In sukuk. Paper presented at the Shariah Forum, KLIFF, 23 September 2013,

Farisulhaq, M., Rizki, F. S., \& Rojak, E. A. (2019). Tinjauan Fikih Muamalah terhadap Implementasi Akad Mudharabah pada Produk Sukuk Ritel di Bank Syariah Mandiri KC Ahmad Yani Bandung. Prosiding Hukum Ekonomi Syariah, Vol. 5, No. 2.

Fadhilah, M. F.,. (2011). Sukuk Mudharabah. Al-Iqtishad. Vol III, No. 1, Januari 2011.

Fasa, M. I. (2016), Manajemen Resiko Perbankan Syariah Di Indonesia. Li Falah, Vol 1, No. 2, Desember 2016.

Fatwa Dewan Syariah Nasional No: 115/DSN-MUI/IX/2017 Tentang Akad Mudharabah

Fatwa Dewan Syariah Nasional No: NO: 87/DSN-MUI/XII/2012 Tentang Metode Perataan Penghasilan (Income Smoothing) Dana Pihak Ketiga

Fatwa Dewan Syariah Nasional No. 32/DSN-MUI/IX/2002 Tentang Obligasi Syariah

Fatwa Dewan Syariah Nasional No. 33/DSN-MUI/IX/2002 Tentang Obligasi Syariah Mudaharabah

Fatwa Dewan Syariah Nasional No. 105/DSN-MUI/X/2016 Tentang Penjaminan Pengembalian Modal Pembiayaan Mudharabah, Musyarakah, dan Wakalah bil Istitsmar 
Febriani, A. N. \& Mala, T. (2013). Analisis Pengaruh Suku Bunga, Inflasi Dan Nilai Tukar Rupiah Terhadap Imbal Hasil Sukuk Mudharabah Di Indonesia. Jurnal Ekonomi Pembangunan, Vol. 2, No. 3, September 2013.

Fitrah, M. \& Luthfiyah. (2017). Metodologi Penelitian, Penelitian Kualitatif, Tindakan Kelas dan Studi Kasus. Sukabumi: CV Jejak.

Karim, A. (2013). Bank Islam: Analisis Fiqih dan Keuangan. Jakarta: Raja Grafindo Persada.

Lahsana, A. \& Lin, L. S. (2012). Issues in Islamic Capital Markets: Islamic Bond/Sukuk. Proceeding of International Conference on Business and Economic Research, 12-13 March 2012.

Mutia, E., Rahmawati, \& Afrianandra, C. (2018). Value at Risk of Sukuk Ijarah and Mudharabah in Indonesia. Journal of Accounting Research, Organization an Economic, Vol 1, No.1, pp. 65-73.

Muhamad. (2004). Teknik Perbitungan Bagi Hasil Dan Pricing Di Bank Syariah. Yogyakarta: UII Press.

Morni, F. (2019). A Thematic Literature Review On Sukuk. IJIE, Vol. 1, No. 2, July-Desember 2019.

Meirinaldi \& Astuti, P. (2017). Analisa Faktor-Faktor Yang Mempengaruhi Peringkat Sukuk (Studi Kasus Pada Perusahaan Penerbit Sukuk Non Keuangan). Jurnal Ekonomi, Vol. 19, No. 2, Juni 2017.

Nasrullah, A., Burhan, U., \& Multifah. (2013). Studi Keptuhan Syariah Dan Manfaat Ekonomi Terhadap Minat Investor Dalam Pembelian Sukuk Negara. La Riba, Jurnal Ekonomi Islam, Vol VII, No. 1, Juli 2013.

Noor, M. A. \& Haron, M. N. (2015). Aplikasi Tanazul dan Isu-Isu Syariah Dalam Sukuk Berasaskan Kontrak Ekuiti, Jurnal Muamalat, Bil. 8.

Otoritas Jasa Keuangan. (2019). Data Statistik Sukuk. https://www.ojk.go.id/id/kanal/syariah/ data-dan-statistik/data-produk-obligasi-syariah/Documents/Pages/-Statistik-SukukSyariah---Februari-2020/Statistik\%20Sukuk\%20Februari\%202020.pdf

Pramananda, R. L. (2014). Mudharabah: Sebuah Dilema. IBEC FEBUI, 2014 http://www.ibecfebui.com/mudharabah-sebuah-dilema/ Diakses 8 April 2020 pukul 12:48

Rahman, H. M. (2018). Mudharabah and its Aplications in Islamic Finance: An Analysis. Asian Journal of Research in Banking and Finance, Vol. 8, No. 6, Juni 2018.

Rahmawati, E. N. \& Ghani, A. M. (2017). Akad Penerbitan Sukuk di Pasar Modal Indonesia dalam Perspektif Fikih. Al-'Adalah, Vol. 14, No. 1.

Sapuan, N. M. (2016). An Evolution Of Mudharabah Contract: A Viewpoint From Classical and Contemporary Islamic Scholars. Procedia Economics and Finance, 35, pp. 349-358.

Sarana Multi Infrastruktur. (2018). Prospektus Green Bond dan Green Sukuk 2018 PT-SMI. https://www.ptsmi.co.id/wp-content/uploads/2018/07/Prospektus-Green-Bond-danGreen-Sukuk-2018-PT-SMI.pdf

Sartono, A. (2001). Manajemen Keuangan Teori dan Aplikasi. Yogyakarta: BPFE

Soemitra, A. (2009). Bank dan Lembaga Kenangan Syariah. Jakarta: Kencana

Solisa, D. N. (2017). Profit Equalization Reserve (PER) Sebagai Upaya Mitigasi Resiko Imbal Hasil Perbankan Syari'ah (Suatu Kajian dengan Pendekatan Maqasid asy-Syariah). Az-Zarqa', Vol. 9, No. 1, Juni 2017.

Uddin, M. A. , Sultan, Y., Hosen, M., \& Ullah, N. (2015). A Critical Analysis Of Islamic Bond: A Case Study On Sunway Treasury Sukuk. MPRA Paper No. 68785, Posted 12 Jan 2016 12:49 UTC. https://mpra.ub.uni-muenchen.de/68785/

Widayat. (2010). Penentu Perilaku Berinvestasi. Ekonomika-Bisnis, Vol. 01, No.02, Juni 2010.

Yahya, M. \& Gunanto, A, \& Yusuf, E. (2011). Teori Bagi Hasil (Profit And Loss Sharing) Dan Perbankan Syariah Dalam Ekonomi Syariah. Jurnal Dinamika Ekonomi Pembangunan, Vol: 1, No. 1, Juli 2011.

Zadeh, E. L. (2016). Shariah Issues Relating To An Islamic Security-Sukuk. EPRA International Journal of Economic and Business Review, Vol. 4, Issue-2, February 2016. 